\title{
Wine Diversity: Paradox or Economic Innovation?
}

\author{
Geneviève Teil ${ }^{1 *}$ \\ ${ }^{1}$ INRAE SAD APT, AgroParisTech, Paris-Saclay University, FRANCE
}

*Corresponding Author: genevieve.teil@agroparistech.fr

Citation: Teil, G. (2021). Wine Diversity: Paradox or Economic Innovation?, Journal of Cultural Analysis and Social Change, 6(2), 13. https://doi.org/10.20897/jcasc/11451

Published: December 28, 2021

\begin{abstract}
This article examines the extreme differentiation within the wine market, which economists view as an aberration. Drawing on empirical material from previous studies and historical texts, it argues that the wine market's organization has evolved over the 20th century towards a split between two different economic regimes: one 'standard', which conforms to and is conformed by economics, and one alternative, which is more akin to the art market. Their differences pertain to processes of qualification (Callon) or materialization (Slater, 2002), with the former leading to a stabilization of quality and the latter to its unstabilization. The peculiarity of this unstabilized-quality market affords insights into the continued growth of the number of wine references on the market, despite its economic oddity.
\end{abstract}

Keywords: economicization, economic regimes, quality certification, geographic indications, wine exploration

\section{INTRODUCTION: THE DANGER OF EXTREME DIFFERENTIATION ON THE WINE MARKET}

France's wine consumption has been declining since the 1960s. In 2000, French wine exports also started slowing down, while varietal wines from new producing countries were making their way onto the French market with a promising future ahead of them. At the time, many critics pointed to the excessive number of French wine appellations - of which there were over 450 - and raised the question of how consumers were supposed to make sense of them. With ' $35 \%$ of surveyed consumers unaware of the meaning of the three letters AOC' (César, 2002), how could a Chinese or Californian consumer find their way through the 'jungle' of French wine names? Although determining the socially optimal degree of differentiation, or even how far or close a market is to it, appears to be a daunting task, economists assert that excessive diversity is detrimental to the proper functioning of the market (Dixit and Stiglitz, 1977; Lancaster, 1975; Spence, 1976). The wine market, with its hundreds of thousands of brands, types and vintages, seemed to have exceeded all reasonable limits. It had to be simplified! The five or six main grape varieties that structure the world's supply had to bring their visibility back to French wines and facilitate exports.

\section{The Diversity of Wines: A Blindspot in Research on the Wine Economy}

Twenty years later, these arguments no longer seem quite as self-evident, as the main grape varieties have become less fashionable, and the number of appellations continues to grow. Is the French wine offer's diversification disease flaring up again? Or is wine fuelling a particular kind of market, characterized by a plethoric supply of products? What do studies on the economics of wine say? Wine has generated an exceptional amount of research in economics, aptly summed up by Chaikind (2012): 
No other good can come close to the diverse range of applications as wine can, whether as an agricultural commodity, an investment good, a cornerstone of international trade, a contributor to price theory, or even as a form of investment in human capital.

Yet, surprisingly, Chaikind (2012) fails to mention a longstanding feature of the wine market: its extreme differentiation. Karl Storchmann, founder and managing editor of the Journal of Wine Economics, provides a concise list of the questions to which the wine economy has given rise: '(1) the value of wine as an alternative financial asset, (2) wine and climate change, and (3) wine and expert opinion' (Storchmann, 2012). The wine market's diversity is not among them.

One may assume that these researchers see this particularity as both artificial and illusory, merely a plethora of different labels on very similar products which can, moreover, be held responsible for this market's specific dysfunctions: The considerable dispersion of wine prices (Combris et al., 1997; Costanigro et al., 2007), and the existence of wine critics and quality signs which, instead of informing consumers on the quality of wines, only parasitize the adjustment of prices and qualities (Ashenfelter, 1992; Ashenfelter and Jones, 2013; Cardebat et al., 2014; Friberg and Grönqvist, 2012; Rössel and Beckert, 2013). The multitude of labels, an economic aberration, may thus result from wine's particular 'symbolic charge' stemming from a dense layer of socio-cultural history that is assumed to weigh down on the market's proper functioning. Studies of wine consumption have sought to decipher this layer. In line with the work of Warde (1994), Demossier (2005) studied recent changes in wine consumption and in attention to the quality, naturalness, origin, or authenticity of wines, in search of the underlying processes of identity and distinction to which they bear witness. Here, wine is seen as the clay in a social modelling process that is deemed to tamper with economic exchanges. Wine diversity should henceforth be a matter of sociology rather than economics.

Karpik (2007) finds it surprising that economics had not taken more interest in this peculiarity of the wine market. His explanation for this is that, because neoclassical economics assumes goods of the same denomination to be homogeneous, it overlooks vast ranges of products and services which, on the contrary, are 'incommensurable'. In the rest of his book, he proceeds to explain the particular workings of this market of heterogeneous goods that are 'marked by uncertainty about quality', yet which all share the same broad denomination: wine, lawyers, doctors and psychoanalysts, cultural productions such as novels, films, records, plays, paintings, and so on. However, Karpik's (2007) interpretation relies on the assumption that these products cannot be compared-which in itself is as questionable as the homogeneity of the goods, the notion against which he argues. Absolutely heterogeneous singularities cannot have a degree of quality; they can only be themselves. Whenever quality, however uncertain it may be, is among the attributes of things, they are comparable. Irrespective of their differences, two goods can always be compared, if only from the point of view of their usefulness or their general quality; whatever their particularities, two wines can always be compared as wines. This is the whole purpose of blind tasting tests; by concealing any other form of difference, they subject different wines to comparison as wines.

\section{Quality as a Process of Qualification and 'Materialization'}

Whether they belong to the field of economics or sociology, all the aforementioned works have one thing in common: they take taste and quality as a given, and thus fail to understand how quality results from economic action and, in turn, structures this very action.

Slater (2002) took a decisive step in this direction. He took up Lancaster's (1971) analysis of any economic good as a 'bundle of characteristics', but interpreted it in an original way. The elements that characterize a good, he argued, do not 'spring out' of its essential nature, but instead stem from a process of 'materialization' within economic activity. With this notion, Slater refuses not only the division between natural and symbolic propertieswhich is always opportunistic and arbitrary —along with the idea that an object's qualities are given a priori, but also the division between what is social and what is economic:

[W] do not live in a 'more cultural' economy, or a society of the sign, or an enculturated economy but we do live in a world that has opened up the black box of the social object, institutionalising and rendering reflexive processes which were always incipient. Hence, we live in a world of increasing instability at the level of material culture, and one which is driven by strategies of stabilization and destabilization, by contests over the materiality of the social world itself (Slater, 2002: 107).

Quality, be it stabilized or destabilized, is never the pre-existing 'given' that economic or sociological studies take it to be. A good's quality is always the result of a process of producing this quality-a process that is framed to varying degrees and is never predetermined or performative. Slater takes up the work of Callon (1998a, 1998b), who ponders the strange duplicity of the French word 'économie', which makes no distinction between economic activity and the science of economics, whereas the latter models the former to better discipline it. Callon et al. 
(2002) emphasize the importance of product qualification and requalification, which result in a process of constant 'economicization' (Calıskan and Callon, 2009, 2010) and give rise to the emergence of economic 'goods', the qualitative existence of which economics hastily freezes.

The shift in viewpoint that these authors introduce allows us to re-examine the question of wine differentiation. Perhaps the diversity of wines appears to be a sort of aberration from the point of view of economics because the (re-)qualification or materialization process does not bring about the expected stabilization of quality. This calls for a closer look at this materialization process, to understand wine's resistance to offer 'qualculations' (Cochoy, 2002; Callon and Muniesa, 2003), materializations and categorizations, and, ultimately, to articulate the alternative that results from it.

To this end, this article leaves aside social interpretations of wine differentiation (Demossier, 2001, 2010; Rössel et al., 2018) that rest upon a state of affairs - the vast differentiation of the wine offers-but which do not provide an account of, or an explanation for, its emergence or persistence. Instead, I adopt a pragmatist posture, as laid out by James (1996) in which the focus is on accounting for the process through which the world as we know it emerges, rather than on searching for the causes from which it might result. To pinpoint the processes of construction of wine diversity, I will pull the thread of winegrowers' increasing criticism, that is gather and analyze their increasing complaints regarding the 'standardization' and 'uniformization' of wines since the 1970s. These grievances were a leitmotif in interviews held with wine producers during two series of field surveys: one on the quality of wines in France, run mainly in the Pays de Loire and the South of France from 1998 to 2008; and the other on the notion of terroir in the face of climate change, run from 2014 to 2017 in Alsace and the Pays de Loire. Hundreds of interviews were held over the course of these surveys, in which various stakeholders in the wine industry, most of whom were winegrowers, described their wine production and marketing activities and commented on them. Using the concept of 'materialization' as Slater so aptly defined it, the present analysis focuses on these complaints and criticisms, to understand what alternative mode of materialization these producers aspire to when they denounce the standardization of wines.

The article opens with a brief historical overview of the birth of Appellations d'Origine Contrôlée in France. Producers' grievances are rooted in diverging interpretations of the 'guarantee' and 'spirit' of appellations of origin, with economists' criticisms focusing on the former and appellation winemakers on the latter. The first part of this article therefore provides a brief historical overview of the birth of appellations of origin in France. The second part presents a reinterpretation of divergences regarding the qualification of wines as the emergence of two market regimes with opposite processes of materialization. In the conclusion, I discuss a possible 'artification' of wine in one of these market regimes.

\section{RECOVERING THE PAST QUALITY OF WINES}

Variety in wines is nothing new. Since ancient times, the offer has been structured according to wine's colour, origin, grape variety, vinification technique, or vintage, and the quality of wines has long drawn attention in places of power. ${ }^{1}$ The wine industry underwent a serious crisis in the late $19^{\text {th }}$ century, when phylloxera gradually invaded all European vineyards and halted the production of fresh grapes for several years. This had a profound effect on the organization of the market, as winegrowers had to resort to radical innovations to make up for the lack of grapes. They used grapes from the French colonies, notably Algeria, and from countries like Australia and South Africa, or from new hybrid varieties of American vines that were resistant to the disease, or even rehydrated raisins, musts, or recomposed wines based on mixtures of their main ingredients: tartaric acid, sugar, alcohol, tannins, and a panoply of adjuvants and colorants intended to emulate the usual appearance and taste of wine. Once the crisis was over, these innovations, which had profoundly diversified production methods, were deemed to be a threat, not only to the identity and quality of wines, but also to the relevance of the categories that structured the market.

In the $19^{\text {th }}$ and early $20^{\text {th }}$ centuries, the French wine industry was thus struck with a succession of laws that were passed at an unprecedented rate in an effort to regulate the production and denominations of wines (Stanziani, 2003a, 2003b). This legislative endeavour spawned a series of texts on appellations of origin that led to the famous 1935 law on appellations of controlled origin ${ }^{2}$ (AOC), the success of which would be matched only by the hostility and conflicts it generated.

AOC regulations stipulate the conditions to which all producers wishing to identify their wine by the name of their geographical origin must adhere. They list production constraints pertaining to viticulture: 'local, fair, and

\footnotetext{
${ }^{1}$ Besides the famous 1395 edict by Philip the Bold, Duke of Burgundy, prohibiting the cultivation of Gamay, numerous other royal edicts and regulations were aimed at preserving the reputation and quality of wines in France and elsewhere, including Spain (Universidad de Valladolid, 1975).

${ }^{2}$ République Française (1935). Décret-loi du 30 juillet 1935 Défense du marché des vins et régime économique de l'alcool. JORF du 31 juillet 1935 8314-8319.
}

(C) 2021 by Author/s 
consistent practices' 3 in the choice of grape varieties, vine size, yields, vinification techniques, and above all the place where the grapes are grown. Appellation regulations also set out standards for the final product: thresholds concerning the acetic acid, alcohol, and sugar content of the wines, which can be associated with consensual defects, such as acetic tainting (vinegar acid spoilage), or can compromise wine conservation, such as a lack of alcohol.

As names of origins are exclusively associated with a place of production, these appellations of origin'Châteauneuf du Pape' or 'Alsace', for instance_establish a monopoly on the production of wines in these geographic areas and thus introduce a 'wart' in trademark law, which is a source of acute tension within international trade regulation bodies. Yet a growing number of countries that use appellations of origin are adopting this regulation to protect their emblematic local products (Porto, Madeira, Rioja, etc.). More surprisingly, from the 1970s onwards, appellations became the focus of intense tensions among the very people who use them to differentiate their production: winegrowers whose products bear these appellations.

\section{AOCs' Guarantee of Means}

Appellations of origin guarantee that a product has been manufactured according to a certain process, rather than the actual result of the process, that is, the final taste of the wine. Around 1900, Joseph Capus and the Baron Le Roy justified their crusade for the defence of appellations of origin by claiming that the quality of French wines, which had made their reputation throughout the world, was collapsing. They therefore wanted to provide impetus for a movement to 'seek quality' (Capus, 1906) which required a specific long-term vision of production and marketing:

I wanted to show that once you have adopted the movement towards quality, you cannot stop. Quality is always perfectible because it is essentially a human endeavour. It demands momentary sacrifices, but the payoff is ample in the future. (Baron Le Roy, quoted in Cofradep, 1974a: 411).

The guarantee of quality therefore relies on a strong guarantee of means. The innovations that had adulterated wines had to be swept away and quality had to be worked on again, starting from the bases that had made its reputation, those 'local, fair and consistent practices' mentioned in the law. Yet as the result of this work was not anticipated in any precise way, the constraints regarding the end result were limited to rejecting a few consensual defects.

\section{Economic Research's Critique of AOCs: The Failure of Materialization Stabilization}

This guarantee of means, which also exists in the medical profession, for example, has been criticized by many economists. In the 1970s, quality became a central concern in economics (Leontief, 1959; Nelson, 1970; Stiglitz, 1987). Market goods no longer only had an identity allowing them to be grouped into broad categories (milk, wine, cars, etc.), but also had different qualities among goods of the same denomination. If the name no longer suffices to know what one is buying, consumers depend on the information they can acquire or can be given about a good. Delays or costs in the acquisition of quality information by the consumer are seen as a source of market failures, or even as a threat of market collapse (Akerlof, 1970). To counter this, producers or states can create signs conveying 'information' on quality, such as AOCs, for instance.

Due to market imperfections, the interests of producers, processors, regions and states in protecting geographical indications for their high-quality products may be well justified. Regulation at the national or international level may be necessary if intellectual property is ignored or if consumers face quality uncertainty and high search costs. On the other hand, however, it is possible that geographical indications are being used as a new instrument of agricultural protectionism and, thus, reduce economic welfare. (Herrmann and Marauhn, 2009a: 13).

But can a guarantee of means that does not require precise qualitative outcomes constitute a true guarantee of quality? If not, AOCs may only be instruments of disguised protectionism. This is why the measures contained in these regulations are strongly criticized. Not only are appellations of origin suspected of being at odds with the rules of international trade, but some argue that yield caps and the monopolization of a production area are a way to raise prices by artificially maintaining scarcity (Bramley and Kirsten, 2007; Herrmann and Marauhn, 2009; Kerr, 2006; Marette et al., 1999; Teuber, 2010; Thomas et al., 2013). Some have described them as a way to build 'clubs' of producers who control their membership rules (Buchanan, 1965; Thiedig and Sylvander, 2000; Torre, 2002); others see them as illustrations of the complexity of identity construction processes (Gade, 2004). In short, all these studies consider whether appellations of origin, a sign that does not guarantee the emergence of a stabilized

${ }^{3}$ Article 1 of the 5 August 1908 law, amending Article 11 of the 1 August 1905 law on the control of fraud in the sale of goods and of foodstuffs and the falsification of agricultural products. 
quality of the products it protects, can really stand for true quality. Yet, despite this harsh and increasingly strong economic criticism of the guarantee they provide, AOCs are successful in the field. Their numbers have grown steadily over the years, as has the list of countries that have adopted them.

\section{Diverging Opinions Among Winegrowers about AOC Approval Tastings}

There is no doubt in AOC winegrowers' minds that AOCs guarantee the quality of wines. However, tensions arose in 1970 when, in an attempt to bolster AOCs' guarantee of results, the European administration required that approval tastings be generalized in AOCs (Cee, 1970). These consist of a taste test to validate the quality of wines applying for the AOC, conducted by a panel of producers of the appellation.

A committee of producers for the defence and promotion of the quality of AOC wines and spirits, COFRADEP, claimed that this initiative ruined "the very substance and foundation of the legal doctrine of AOCs, which are being called into question against an eminently subjective, inconsistent and imprecise criterion" (Cofradep, 1974c: 370).

Compulsory tasting, as it is designed, cannot be considered as a measure of sufficient selectiveness. It can only give a label to wines that have no significant organoleptic defects, but they may also have no true personality. It therefore has the characteristics of mass selection, which inevitably leads to mass production (Cofradep, 1974b: 473).

COFRADEP challenges the approval jury's ability and legitimacy to evaluate and discriminate between producers' various products. This is supported by the fact that, in the appellations that have adopted this practice, juries refuse only those products that are unanimously deemed to be defective-and do so only very seldomlywhile pointing their producers towards technical avenues for eliminating these defects. This liberal interpretation of the concept of approval tasting supports the idea that AOCs' guarantee is an illusion. How could one claim to certify quality while simultaneously accepting everyone — or almost everyone?

In the late 1990s, the search for quality intensified around the notion of terroir (Teil, 2012). Producers sought to limit their intervention in the wine-making process, to leave more room for vine and terroir expression. The resulting technical change, and especially the use of more environmentally friendly techniques, introduced a new gustatory variety upheld by the producers behind it; this in turn intensified the conflict around approval tastings. Producers of recognized wines are turned down by AOC tasting panels on the grounds of a lack of typicality. When they refuse to correct their wines, they have to market them as table wines, but they do so with labels that ridicule appellations, as well as very high prices that differentiate them from 'other' table wines (Teil et al., 2011). These producers thus contribute to destabilizing the hierarchies and categorizations that structure the market.

In 2008, a European reform of the appellations of origin re-ignited the debate on the definition of typicality. It required producers to objectify better their link to their terroir, which included explicitly articulating the typicality of their wines, that is, the few 'objective' taste criteria proving that wines from one appellation are different from those of the next appellation. However, objectifying the quality of wines in this way leads to a standardization of their taste, thus precluding any pursuit of gustative quality. This makes some heads of the appellation watchdog committees very uncomfortable:

I've steered the accreditation document towards something that's practically void. There's nothing. There are really just the big flaws and that's it. I felt very bad about ... I felt like, you know, like I was betraying my winegrowers. And, honestly, if I'd put in things that were too specific-because there are strong personalities and I find their interpretation wonderful and so, to jam them into a form-it made me sick. So, rightly or wrongly, I chose the option of having a very, very standard form. [...] for me, the more detailed the grid is, the more it standardizes the wines." (AOP Chairman, 2012).

In line with economists and the European administration, other appellation executives are in favour of a stricter definition of typicality to limit the variability of wines. But when they advocate for tighter framing of wines' gustatory quality — as they did in Alsace, with a more assertive 'dry, bright and fresh' typicality — they are accused of 'standardizing', 'normalizing', and 'homogenizing' the quality of the appellation's wines. Conversely, their opponents call for 'opening up the range of diversity within each appellation even further because the personalities of each winemaker would shine through even more' (Winemaker BP4, Pays de Loire, 2012). They reject the idea of typicality and prefer the more open idea of wine 'style':

4 The two letters "BP", and further on "RG", "BC", and so on, are identification codes for the winegrowers I quote.

(C) 2021 by Author/s 
Type, typicality, is the best way to become linear, single-minded. And thus, to abolish creativity. For a start, specification charters are the first step towards abolishing creativity. Go ask an artist to follow imposed specifications! (Winemaker RG, Pays de Loire, 2012).

\section{The Interplay Between Toughening and Relaxing Means or Results Obligations}

The world is changing, especially in agriculture, where the weather has a determining impact on production. Promises to stabilize taste quality require a set of resources allowing producers to correct deviations: in particular, those due to unstable climatic conditions, but also regulatory or even geopolitical variations. Producers in favour of more explicit typicality are therefore simultaneously demanding greater flexibility in the constraints that appellation regulations impose on means. Their detractors, on the other hand, advocate for the exact opposite: tightening constraints to better control the quest for quality and prevent it from going down certain slippery technical and commercial slopes. It is not for the consumer to say what the quality of the terroir is, but for the terroir and the winegrower's work to bring it out. They oppose the subjugation of 'industrial' quality to 'commercial demand', and call for the prohibition of all the adjuvants or corrective practices their opponents depend on to erase gustatory deviations from their model of typicality. They deem intolerable the ways in which winegrowers are allowed to intervene upon the expression of the terroir.

In an effort to mediate this conflict, scientists are studying the notion of terroir, a combination of agro-geoclimatology and human know-how, and its gustatory correlate, typicality (Bohmrich, 1996; Salette, 1997). They are looking for determinants of the typical quality of AOCs, or a way to characterize it. While this research effort is causing the list of terroir determinants to grow, controversy persists regardless (Teil, 2012). The rift between two interpretations of terroir and typicality is widening, with, on the one hand, the idea of a predefined gustatory quality, attested by the past or present reputation of the appellation's wines, and, on the other hand, that of a quality that is also attested by their past reputation, but is to be sought or found again. The main bone of contention is the question of who should define gustatory quality, and what the acceptable level of variability in quality should be:

We just have a choice to make: either you're an industrial producer [and] what interests you is to have a production ratio compared to a raw material investment ratio. And then, you try to optimize that by making sure that customers get what they want and [...] upstream, [you think] 'what are they expecting and how do I get that?' [...]. Either that's your thing, or you're in an approach where you think: what I'm interested in is not so much the ratio of production to what I put in so that I can earn more money, as the fact that what I'm going to produce can tell a story to the person who's going to consume it. After that, it's up to me to find a way to add value that will justify the price I can put on the table so that the consumer will want to buy it, so that I can also make it work financially. (BC winegrower, Pays de Loire, 2012).

Of course, winemakers who criticize the 'industrial' mode are not uninterested in their sales. But, as the winemaker quoted above points out, they arrange the commercial agreement between their wines and consumers in other ways, which result in two contrasting views of production and in different distribution channels.

\section{ENCOURAGING ENTHUSIAST CONSUMERS TO EXPLORE WINE}

Economists often analyse wine as an experience good (Darby and Karni, 1973; Nelson, 1970), that is, a commodity that cannot be known before purchase. Although it may seem obvious, since wine is housed in a sealed bottle, this assumption is actually quite paradoxical. As an agricultural product with an annual harvest, the supply of wine is largely renewed with each vintage. But, short of the occasional accident, two bottles of the same batch can be considered as being as similar as two cans of the same food, two pencils or two leeks. While the first bottle of a given wine that one enjoys can be considered as an experience good, the second one cannot. The idea that wine is an experience good therefore relies on the assumption that knowledge of wine does not inform consumers, and that they do not buy wines whose quality they know from experience. Yet wine can nevertheless also rightly be seen as an experience good, because consumers very regularly repeat this experience by buying wines they do not know. This is not the case of all wine buyers; the idea of wine as an 'experience good' points to an essential characteristic of those of them who readily call themselves 'curious': the enthusiasts.

A previous analysis of these enthusiasts' activity over the long term Teil (2021) examines the transformations it brings about. Enthusiasts, whom (Demossier, 2005, 2010) describes as disloyal, vagabond customers, are different from other consumers insofar as they are embarked upon an exploration of wine that is fuelled by the new wines they find. Yet despite their exploratory tasting activity, they do not develop a more precise knowledge of good quality and of their tastes, which would restrict the range of their purchases once they had done the rounds. Instead, after a somewhat normative period of learning about good quality or tasting skills, it leads to a sort of 
gradual dissolution, both of tastes and of qualities, understood as specific characteristics of tasters and wines, and of the rules and practices of proper perception. To maintain their exploratory passion, enthusiasts progressively discard, eliminate, and overcome all the obstacles that could limit its deployment, starting with their 'tastes' and the results of past experiences, and including 'fashions' and any imposed 'norms'. Thus liberated, tasting becomes an experience: with each new tasting, the symmetrical emergence of the enthusiast's tastes and of the taste of things is renewed. Unrestrained, it also becomes more imponderable and surprising. Alongside discoveries and novelties, exploration is also progressively supported and stimulated by variations between tasting contexts and conditions; it is nourished by the very renewal of experiences. Unlike a standard drinker, a negative experience does not lead the enthusiast to reject a wine, as a bad impression can always be due to bad tasting conditions. Passion is not extinguished by bad wines, but rather by the weariness that comes with routine and predictable tastings: the world to be explored then shows its limits and boredom lurks.

In the course of an enthusiast's practice, tastes and qualities become a result that is always provisional, pending the next tasting. Their consumption activity thus contrasts sharply with sociological or economic interpretations of tastes as characteristics of the subjects and objects of taste. Enthusiasts' curiosity is not a psychological characteristic; it points to their exploratory activity, which is all the more active as it is fuelled by a wide variety of products that maintain a perpetual renewal of qualities and tastes. These are the core customers of winemakers who refuse 'standardization', that is, the stabilization of their wines' qualities.

\section{A 'Materialization' with Maintained Instability}

To adjust to consumer-enthusiasts, winegrowers cannot rely on tastes since-due to the exploratory process in which consumers are engaged-these are neither stabilized by habitual practice nor stabilizable through sophisticated marketing processes. While these consumers are reluctant to follow their tastes, which restrict discovery, they are, on the other hand, particularly open to new products as they keep expanding their field of exploration. They are also avid readers of the wine press, wine guides, and books that publicize 'up-and-coming wineries' and all the neglected treasures of the wine world. While they do not disdain supermarkets, they have little faith that their retailers' purchasing managers will find wines of interest to them. They therefore tend to visit supermarkets as opportunists, to find 'bargains' and sometimes 'surprises', especially during seasonal wine fairs. Becoming connoisseurs does not mean that they trust only their own experience. Taste is a matter of sharing, because the experience of others is also an effective way to renew and enrich one's own tasting experience. They therefore prefer 'contact' with selected retailers, known for their passion for wine, or with winegrowers themselves, as shown by the rise of 'wine tourism'.

The 'market agencing' (Callon, 2013) underlying this alternative mode is based on an original process of materialization that in a sense defies both Slater's term 'materialization' and Callon's term 'qualification'. Instead of stabilizing the attachment between products and consumers, it fuels the renewal of tastes and qualities, thus also sustaining the renewal of attachments. While 'materialization', the realization of a particular attachment between a wine and a wine lover, does indeed happen, it is always temporary, because it contains the seed of its own evolution. It is therefore not only diverse depending on the person and the wine, but also never stabilized.

\section{The Emergence of an 'Exploratory’ Market Regime}

The encounter between these wines and the enthusiasts who buy them-and who are as inclined towards exploration as the winegrowers are-contributes to the emergence of a very particular market regime. Enthusiasts' exploration of tastes relies on the experience of multiple tasters: winegrowers as well as people in intermediary businesses that specialize in this regime-specialized retailers, critic journalists, sommeliers—and other connoisseur enthusiasts. Their purchases are underpinned by a very large number of tasting reports, be they written, in guidebooks, wine magazines, and tasting notes from enthusiasts, or oral, in conversations with sellers, producers, and other enthusiasts. All these tastings mostly provide strongly divergent reports. Yet this divergence is a sign not of dysfunctions but, on the contrary, of intense gustatory activity.

Enthusiasts' exploration of wine is above all gustatory; what drives them is discovering the tastes of wines. It is often said that wine enthusiasts drink up more stories than they do wine, but these 'stories' are very different from the constructions marketers come up with ad hoc to suggest a style or boost an impression. The exploration of wine's tastes contributes to a movement to constantly open up new areas in, for instance, wine-making techniques, the geography of production, ampelography, or winegrowers' work with their terroir.

Finally, when a producer-driven quest for quality fuels buyers' exploratory practice, a particular market is established. It allows wines and their qualities to proliferate, while simultaneously giving rise to a particular kind of competition between producers, where the goal is to produce wines likely to feed the passion of enthusiasts. This regime is based on an original framing and organization of the commercial agreement between the product and its buyer, although in both cases sales remain the ultimate test of success. As it takes place in the 'standard', regular economic regime, 'materialization' leads to a stabilized, and therefore constantly re-stabilized, adjustment between 
the taste of wine and consumer expectations. In this other, 'exploratory', regime, 'materialization' is based on the renewal of qualities and tastes. It must sustain the passion of wine enthusiasts by encouraging them to explore products, spaces, and techniques which, by renewing the taste of wines, keeps stimulating their appetite for discovery and surprises. It is therefore not surprising that, contrary to the requirements of the standard commercial agreement, controlled stabilization is foreign to the techniques, commercial intermediaries, and overall marketing channels that this system uses.

\section{TWO ANTINOMIC REGIMES}

The growing divergence reveals two groups that are subject to the same regulations on appellations of origin, but whose coexistence is constantly fuelling conflict, since the two production and marketing systems that are emerging are structured around opposing and increasingly incompatible interpretations of regulations and principles.

The first regime can be termed 'standard' and is focused on the 'materialization' of a stabilized quality. This quality reaches far beyond taste, to the presentation of the whole bottle, which marketing techniques lock in to a 'demand', that is, a set of buyers with sufficiently stabilized behaviours, attachments, habits, tastes, and qualitative expectations (Harvey et al., 2014). The very fact of articulating a quality allows these consumers to 'know what they want'; it objectifies and supports the structuring and performative nature of these tastes and expectations. Consumers' tastes are no more definitively stabilized than is the weather, and marketers scrutinize their evolution with the utmost attention, to adjust products to them. If consumers are shown to be developing a sweeter tooth, a tiny increase in the residual sugar levels of wines will give them that slightly softer character that will be pleasant without even being noticed. Quality is constantly being redefined, yet these changes are kept discreet, to avoid arousing drinkers' reflexivity; if they were to start questioning their tastes, they might change. Throughout the transformations it undergoes, the wine must keep its identity. Product communication remains tightly restrained and controlled. The main medium is the bottle label, which articulates the wine's gustatory quality to a product presentation, some legal information, a brand name and, above all, an appellation of origin which positions the wine within a competitive environment. This 'materialization', which stabilizes tastes and qualities, goes hand-inhand with the emergence of what Callon et al. (2002) call 'a good'. It supports work upstream from it on planning and financially optimizing the use of resources and the production process. It also allows vine yields to be monitored in relation to forecasted production volumes and price thresholds which ensure the company's longevity.

As they are not engaged in the same pursuit of quality as those who have chosen the opposite path, these producers are commonly accused of supplying low-quality products, supposedly evidenced by their generally rather contained prices. Yet, quite to the contrary, this 'standard' regime does not entail low-cost, low-quality volume production, but rather a stabilized and expected quality that serves as groundwork for steering production and sales.

The second, 'exploratory', regime presents a very different framework, as quality is never a predefined and stabilized given here. The search for quality leads winegrowers to work with those resources that are left unrestricted by appellation regulations: viticulture techniques, grape varieties that appellation regulations treat as 'secondary', and, more incidentally, yeasts. ${ }^{5}$ They are constantly revisiting and reinterpreting old methods, or identifying new techniques to experiment with and areas to explore: grassing, pruning or not pruning, sunlight on the grapes, access to water, depth of rooting, acid structure of the wines, and so on. This exploratory activity, by the winegrowers this time, preserves variety and maintains renewal of the tastes of the wines offered to those consumers who tend to be enthusiasts.

\section{Reinterpreting Misleading Oppositions}

Here and there, discussions between stakeholders have highlighted differences in product quality, innovation ability, or company size and production volume, in an attempt to discriminate between groups of winegrowers. None of these propositions have ever been maintained. Much like wines produced and sold under the exploratory regime, wines of the standard regime have a quality and a qualitative hierarchy. In the 1990s and 2000s, approval tastings, a source of conflict within AOCs, were compulsory for Vins de Pays, the lowest grade on the quality ladder. They also were compulsory for Vins Délimités de Qualité Supérieure, a category of wines from the old non-controlled appellations of origin of the 1919 law which, despite being intended to be a path towards AOCs (César, 2002), had made approval tastings compulsory from their creation. The difference between the two regimes does not come from quality itself but from its stabilized or unstabilized mode of existence. It is also sometimes drawn along a line

${ }^{5}$ In cheese or cider, microbial ecosystems are the subject of considerable attention, as they produce significant differences in taste.

$8 / 13$

C 2021 by Author/s 
between a rather conservative commercial mode of production, and innovative artist producers. Yet both resort to innovation, albeit according to different principles. While the standard regime's ongoing process of optimizing production organization relies on a constant flow of innovations, the use of those innovations must remain relatively opaque so as not to risk upsetting the way the offer is structured, with its categories informing the commercial agreement. Unless there is an aggressive commercial strategy aimed at destabilizing the market, 'incremental' product innovations, as economists call them, such as 'grapefruit rosé', 'rosé piscine', or 'ice champagne', must slip into the fabric of those categories without tearing it apart. ${ }^{6}$ The exploratory regime is not so cautious, as it never ceases to test and challenge all established categories. Yet far from leading to the kind of confusion the standard regime dreads, this permanent revolution fosters the tasting and appreciation activity of enthusiasts and critics alike. It is structured into 'schools' which delimit a particular field of research: natural wines, terroir wines, quality wines, and so on. Focusing on company size to compare small producers to large industrial units also swiftly leads to a dead end. Quality stabilization and unstabilization is not a matter of production scale, though economies of scale are a very common tool in the pursuit of productivity gains in the standard regime, which takes decisive advantage of the homogenization and stabilization of production categories. Although this is far less common, similar economies of scale can be, and sometimes are, sought in the exploratory regime. Further studies on the subject would certainly yield useful information on the exploratory regime's specific constraints.

\section{Separation or Coexistence}

As antinomic as they may be in their principles and organization, the two regimes we have just described nevertheless share the same product names and regulations, the interpretation of which is a constant source of discord. The radicalization of the differentiation between the standard and the exploratory regimes now raises questions about their coexistence and interaction. How do they interact? What kind of balance between them would be a desirable goal? How can market regulations support the development of both regimes, while respecting their differences? Should the two regimes be separated, and each be provided with legislation better suited to its particular form of marketing?

The latter question arose in the 2000s, at the height of the conflict over the role of approval juries. Should the Indication Géographique Protégée (Geographical Indication of Provenance) (IGP) label (Berthomeau, 2001), which is more lenient, especially when it comes to yield requirements, not be reserved for wines under the standard regime? Conversely, the Appellation d'Origine Contrôlée (AOC) category could then harden its line on wine correction practices, especially chaptalization and the use of sulphur as an antioxidant and antibacterial agent to protect wines. Being largely centred on the question of means, this debate left aside results obligations, and therefore approval tastings. The two options, IGP or AOC, then became signs of 'bad wine', wine that is not submitted to production constraints, or 'good wine', submitted to strong constraints—and, obviously, nobody would readily claim the former.

One solution might be to allow the two interpretations, standard or exploratory, to coexist under the same quality signs, but to adjust the regulatory conditions separately for each case, making them more result-oriented for the former and more means-oriented for the latter-and maybe displaying these options on the label. The merit of this solution would lie in keeping the line between the two regimes somewhat blurred, and not compelling producers to choose between two mutually exclusive options, as not all producers espouse a hard and exclusive interpretation of one of the two regimes. Many of the winemakers with exploratory practices view the standard regime as a way to guarantee some income; to ensure their operation's sustainability, they sometimes back up more personal interpretations of quality with a series of 'cash cow' bottles, more closely aligned with market expectations. Wine marketing channels are not strictly exclusive either; be it on supermarket shelves, in very selective winegrowers' shows, or in varyingly specialized and committed wine shops, marketing structures the difference between the two regimes while maintaining a certain hybridity in their customer base. At the same wine shop, people looking for a good wine for a friend's birthday will be presented with 'a bottle from a recognized appellation and a good vintage', while the enthusiast will leave with 'a very well-rounded vintage from an inventive young man who has recently planted a vineyard in an area that, surprisingly, was ignored by the AOC'. Conversely, not all wine drinkers are either radical enthusiasts chasing after new discoveries or unshakably attached to their preferences. Between these two extremes lies a vast space of consumption choices that hybridize those two consumption behaviours, or even alternate between them.

Nevertheless, these hybridizations and the fact of sharing the same supply categorization framework should not, by default, preclude better separation between different production regimes' regulations-provided the conditions for the cumulative or exclusive use of the two quality signs are carefully examined. The success of the controlled designations of origin's regulation, itself a hybrid effort to guarantee both results and means, should also raise questions as to whether or not this success is due, at least in part, to this hybridity.

\footnotetext{
${ }^{6}$ Unless a company explicitly wishes to transform categorization to its advantage, as pointed out in Slater (2002).
} 
Whichever path is pursued, the interactions between these two systems cannot be ignored. Each contributes differently and complementarily to the market's sustainability, with one facilitating the evolution and transformation of production, and the other contributing to the durability of wines' identity. The two regimes also share a common categorization of supply, although this is used in different ways and is very unevenly rigid in both cases. Appellations delimit families of products, such as Bordeaux or Burgundy, which delimit the offer for standard regime consumers. For enthusiasts, they each open onto a domain to be discovered at first, and all eventually become arbitrarily determined categories of wavering interest. This dual use, with questioning on the one hand and stabilization on the other, is perhaps one of the keys to this market's longevity. It allows the very complex categorization of wine names to continue to stand for qualitative differences while also adapting to a constantly evolving world.

\section{CONCLUSION: TOWARDS AN ‘ARTIFICATION’ OF WINE?}

Studies of the conflicts that have stirred the internal life of the appellations d'origine contrôlées in France over the last few decades show the gradual emergence of two production and marketing regimes with strongly antinomic guidelines. They are very clearly opposed when it comes to the process that Slater (2002) refers to as the 'materialization' of goods. In the first case, which is described as 'standard'. and is in keeping with the hypotheses of standard economics, materialization covers multiple procedures for objectifying and stabilizing 'quality' and consumers' 'expectations' and 'tastes' around a selection of key criteria. In the second case, quality, expectations, and tastes are constantly being invented and revised. Here, the process of 'materialization' does not lead to the stabilization or even the existence of economic 'goods'. It thus defies economics' framing of market activity and its interpretations of 'well-being' as it keeps products and qualities of the same name proliferating.

While the exploratory regime is particularly well developed in the wine sector, it also concerns many other market products, albeit very unevenly. It is undoubtedly supported by all the categories that are committed to organizing, and thus cultivating, variety. Alongside producer brands, designations of origin are a valuable resource in this respect, and they are applied to many food products such as cheeses, olive oils, coffees, and teas. While restrictions on differentiation - such as legislation prohibiting any mention of the origin of milk on labels-are always an obstacle to the exploration of a product's tastes, they are never insurmountable as such. It is, however, always easier to explore an already organized and structured world than a jungle of heterogeneous products.

Finally, while wine - and more generally food products_of specific origin in general tend to be subject to a qualitative differentiation based on taste, any kind of good can be explored in this respect. Examples are shops specializing in soap or fabrics, and the vast production of handicrafts.

It is quite tempting to draw a parallel between wine's exploratory regime and the art market. Both put the same effort into differentiating a 'commercial' version, similarly seen as the result of a social process of distinction, from its exploratory alternative. The latter is a source of constant experimentation and innovation, with its regularly outdated critiques and aesthetic theories, and its unusual proliferation of objects or products that singularly differs from the common consumer goods markets. They also draw the same unusual kinds of consumers: enthusiasts and collectors, who play a decisive role in both diversifying and structuring the world to be explored (Pomian, 1987).

This begs the question: are we looking at an 'artification' of the wine market (Heinich and Shapiro, 2012)? And if so, to what extent is it peculiar to wine, with the rise of the new figure of the artist winegrower (Demossier, 2010)? Or is it, on the contrary, the wine avatar of the aestheticization movement born in the 1950s (Baudrillard, 1970; Featherstone, 2007)?

Aesthetic differentiation and hierarchization in the qualities of wines is nothing new; it has been practised for more than two millennia, especially by the Romans. This makes the idea of a recent 'aestheticization' of wine's standard production and marketing regime sound rather unlikely. Nevertheless, the $20^{\text {th }}$ century has undoubtedly brought about an important evolution, with a clearer differentiation between the two market regimes. This has led to the dual emergence of the exploratory regime and of a standard regime that is bound to a kind of 'democratization' of quality wine. Focusing on aesthetics may be misguided. There has not been a recent wave of aestheticization affecting consumers' cultural matrix, thus transforming the wine market, sweeping it along in its wake, together with technology and eventually the social construction of reality (Welsch, 1996). In their analysis of the contemporary evolution of wine consumption, and specifically of wine evaluation, Rössel et al. (2018) point to a threefold movement towards greater aestheticization, cosmopolitanism and hierarchization. Cosmopolitanism is one of the determining features in the development of enthusiasts' exploratory activity. They push to widen the range of products to be discovered beyond the limits of local or more immediately accessible productions, and constantly re-subject evaluations and hierarchies to tasting, while giving rise to multiple marketable or nonmarketable 'fashion trends' (Liberson, 2000). While wine has not actually become an objet d'art, the increasing differentiation of regimes over the $20^{\text {th }}$ century has strengthened similarities between its market and the art market. 
However, unlike the art market, the current market legislation for wines, and even more so for appellation wines, sets limits to the exploration of quality and taste; hybrid or American grape varieties are forbidden, as are wines with insufficient alcohol content. Although these limits could hypothetically be reformed, they do help to ensure that products are marketed with a specific identity. Yet, for the emergence of an exploratory market to be possible, regulations must leave sufficient space and resources for producers to work on quality and thus deploy a sufficiently varied offer to interest enthusiasts in the appreciation and proliferation of qualities.

While it will most often be constrained by market legislation, the kind of regime that results both from producers and curious enthusiasts' commitment, and from a product's ability to be diversified, is probably not rare. Other markets that also offer a relatively diverse supply are probably home to different versions of it. On the other hand, modes of coexistence, interweaving, hybridization, or juxtaposition between the standard and exploratory regimes in sectors as diverse as apparel, gastronomy, or narcotics could conceal an unexpected complexity-which should be explored.

\section{REFERENCES}

Akerlof, G. A. (1970). The market for 'lemons': Quality uncertainty and the market mechanism. Quaterly Journal of Economics, 84(3), 488-500. https://doi.org/10.2307/1879431

Ashenfelter, O. (1992). Broadbent versus Parker. Liquid Assets, 9(Décembre 1992).

Ashenfelter, O. and Jones, G. V. (2013). The demand for expert opinion: Bordeaux wine. Journal of Wine Economics, 8(3), 285-293. https:// doi.org/10.1017/jwe.2013.22

Baudrillard, J. (1970). La Societé de Consommation [The Consumer Society]. Paris: Denoël.

Berthomeau, J. (2001). Comment mieux positionner les vins Français sur les marchés d'exportation [How to better position French wines on the export markets]. Rapport remis à Jean Glavany, Ministre de l'Agriculture et de la Pêche [Report submitted to Jean Glavany, Minister of Agriculture and Fisheries].

Bohmrich, R. (1996). Terroir: competing perspectives on the roles of soil, climate and people. Journal of Wine Research, 7(1), 33-46. https://doi.org/10.1080/09571269608718059

Bramley, C. and Kirsten, J. F. (2007). Exploring the economic rationale for protecting geographical indicators in agriculture. Agrekon, 46(1), 69-93. https://doi.org/10.1080/03031853.2007.9523761

Buchanan, J. M. (1965). An economic theory of clubs. Economica, 32(125), 1-14. https://doi.org/10.2307/2552442

Caliskan, K. and Callon, M. (2009). Economization, part 1: Shifting attention from the economy towards processes of economization. Economy and Society, 38(3), 369-398. https://doi.org/10.1080/03085140903020580

Calıskan, K. and Callon, M. (2010). Economization, part 2: A research programme for the study of markets. Economy and Society, 39(1), 1-32. https://doi.org/10.1080/03085140903424519

Callon, M. (1998a). Introduction: The embeddedness of economic markets in economics, in M. Callon (ed.), The Laws of the Markets. Oxford UK: Blackwell. https:// doi.org/10.1111/j.1467-954X.1998.tb03468.x

Callon, M. (1998b). The Laws of the Markets. Oxford: Blackwell.

Callon, M. (2013). Qu'est-ce qu'un agencement marchand? [What is a market arrangement?] in M. Callon, M. Akrich, S. Dubuisson-Quellier, C. Grandclément, A. Hennion, B. Latour, A. Mallard, C. Méadel, F. Muniesa, and V. Rabearisoa (eds.), Sociologie des Engagements Marchands [Sociology of Merchant Commitments] (pp.325-440). Paris: Ecole des Mines Transvalor. https://doi.org/10.4000/books.pressesmines.2019

Callon, M. and Muniesa, F. (2003). Les marchés économiques comme dispositifs de calcul [Economic markets as calculating devices]. Réseaux [Networks], 21(122), 189-233. https://doi.org/10.3917/res.122.0189

Callon, M., Méadel, C., and Rabearisoa, V. (2002). The economy of qualities. Economy and Society, 31(2), 28-50. https://doi.org/10.1080/03085140220123126

Capus, J. (1906). La défense des appellations régionales du Département de la Gironde [The defense of the regional appellations of the Department of Gironde]. Document présenté à la session générale de la Société des Viticulteurs de France et d'Ampélographie [Document presented to the general session of the Société des Viticulteurs de France et d'Ampélographie].

Cardebat, J.-M., Figuet, J.-M., and Paroissien, E. (2014). Expert opinion and Bordeaux wine prices: An attempt to correct biases in subjective judgments. Journal of Wine Economics, 9(3), 282-303. https://doi.org/10.1017/ jwe.2014.23

CEE. (1970). Règlement (CEE) nº 817/70 du Conseil, du 28 Avril 1970 [Council Regulation (EEC) No. 817/70 of April 28, 1970]. Journal Officiel des Communautés Européennes, Cee, 817/70 [Official Journal of the European Communities, Cee, 817/70]. 
César, G. (2002). L'avenir de la viticulture Française: Entre tradition et défi du nouveau monde [The future of French viticulture: Between tradition and the challenge of the New World]. Rapport d'information 349 (20012002) de M. Gérard César, fait au nom de la Commission des Affaires Ěconomiques, déposé le 10 Juillet 2002 [Information report 349 (2001-2002) by Mr. Gérard César, made on behalf of the Committee on Economic Affairs, filed on July 10, 2002].

Chaikind, S. (2012). The role of viticulture and enology in the development of economic thought: How wine contributed to modern economic theory. Journal of Wine Economics, 7(2), 213-225. https://doi.org/10.1017/ jwe.2012.17

Cochoy, F. (2002). Une petite histoire du client ou la progressive normalisation du marché et de l'organisation [A little story about the customer or the gradual normalization of the market and the organization]. Revue de Sociologie du Travail [Journal of Sociology of Work], 44, 357-380. https:// doi.org/10.1016/S0038-0296(02)01238-4

COFRADEP. (1974a). Appellations d'origine contrôlées. Le progrès agricole et viticole [Controlled designations of origin. Agricultural and viticultural progress], (1 Juin 1974), 410-413.

COFRADEP. (1974b). Appellations d'origine contrôlées. Le progrès agricole et viticole [Controlled designations of origin. Agricultural and viticultural progress], (15 Juillet 1974), 472-479.

COFRADEP. (1974c). Appellations d'origine contrôlées -- Trois mots pour un programme (suite). Le progrès agricole et viticole [Designations of origin - Three words for a program (continued). Agricultural and viticultural progress], (15 Mai 1974), 364-373.

Combris, P., Lecocq, S., and Visser, M. (1997). Estimation of a hedonic price equation for Bordeaux wine: Does quality matter? Economic Journal, 107(441), 390-402. https:// doi.org/10.1111/j.0013-0133.1997.165.x

Costanigro, M., McCluskey, J. J., and Mittelhammer, R. C. (2007). Segmenting the wine market based on price: Hedonic regression when different prices mean different products. Journal of Agricultural Economics, 58(3), 454466. https://doi.org/10.1111/j.1477-9552.2007.00118.x

Darby, M. R. and Karni, E. (1973). Free competition and the optimal amount of Fraud. Journal of Law and Economics, 16(1), 67-88. https://doi.org/10.1086/466756

Demossier, M. (2001). The quest for identities: Consumption of wine in France. Anthropology of Food. https://doi.org/10.4000/aof.1571

Demossier, M. (2005). Consuming wine in France: The "wandering” drinker and the xin-anomie, in T. Wilson (ed.) Drinking Cultures (pp.129-54). Oxford: Berg.

Demossier, M. (2010). Wine Drinking Culture in France: A National Myth or a Modern Passion? UK: University of Wales Press.

Dixit, A. K. and Stiglitz, J. E. (1977). Monopolistic competition and optimum product diversity. The American Economic Review, 67(3), 297-308.

Featherstone, M. (2007). Consumer Culture and Postmodernism. London: SAGE.

Friberg, R. and Grönqvist, E. (2012). Do expert reviews affect the demand for wine? American Economic Journal: Applied Economics, 4(1), 193-211. https://doi.org/10.1257/app.4.1.193

Gade, D. W. (2004). Tradition, territory, and terroir in French viniculture: Cassis, France, and appellation contrôlée. Annals of the Association of American Geographers, 94(4), 848-867.

Harvey, M., White, L., and Frost, W. (2014). Wine and Identity: Branding, Heritage, Terroir. Hoboken: Taylor and Francis. https://doi.org/10.4324/9780203067604

Heinich, N. and Shapiro, R. (2012). De l'Artification. Enquêtes sur le Passage à l'Art [Of Artification. Investigations on the Transition to Art]. Paris: Éditions de l'EHESS.

Herrmann, R. and Marauhn, T. (2009). The law and economics of geographical indications: Introduction. The Estey Centre Journal of International Law and Trade Policy. The Estey Centre Journal of International Law and Trade Policy, 10(1), 1-8.

James, W. (1996). Essays in Radical Empiricism. New York: University of Nebraska Press \& Longmans Greens and Co.

Karpik, L. (2007). L'Ëconomie des Singularités [The Economics of Singularities]. Paris: Gallimard.

Kerr, W. A. (2006). Enjoying a good port with a clear conscience: Geographic indicators, rent seeking and development. Estey Journal of International Law and Trade Policy. Available at: http:/ /ageconsearch.umn.edu/record/23827/files/07010001.pdf

Lancaster, K. (1971). Consumer Demand: A New Approach. New York: Columbia University Press.

Lancaster, K. (1975). Socially optimal product differentiation. American Economic Review, 65, 567-585.

Leontief, W. (1959). The problem of quality and quantity in economics. Daedalus, 88(4), 622-632.

Liberson, S. (2000). A Matter of Taste: How Names, Fashion, and Culture Change. New Haven: Yale University Press.

Marette, S, Crespi, J. M., and Schiavina, A (1999). The role of common labelling in a context of asymmetric information. European Review of Agricultural Economics, 26(2), 167-178. https://doi.org/10.1093/erae/26.2.167 
Nelson, P. (1970). Information and consumer behavior. Journal of Political Economy, 78(2), 311. https://doi.org/ $10.1086 / 259630$

Pomian, K. (1987). Collectionneurs, Amateurs et Curieux -- Paris, Venise $16^{\circ}-18^{\circ}$ Siècles [Collectors, Amateurs and Curious Paris, Venice 16th -18th Centuries]. Paris: Gallimard.

République Française. (1935). Décret-loi du 30 juillet 1935 Défense du marché des vins et régime économique de l'alcool. JORF du 31 juillet 1935 8314-8319 [Decree-law of July 30, 1935 Defense of the wine market and the economic regime of alcohol. JORF of July 31, 1935 8314-8319].

Rösel, J. and Beckert, J. (2013). Quality classifications in competition: Price formation in the German wine market, in J. Beckert and C. Musselin (eds.), Constructing Quality: The Classification of Goods in Markets (pp. 288-318). Oxford: Oxford University Press. https://doi.org/10.1093/acprof:oso/9780199677573.003.0013

Rössel, J., Schenk, P., and Eppler, D. (2018). The emergence of authentic products: The transformation of wine journalism in Germany, 1947-2008. Journal of Consumer Culture, 18(3), 453-473. https://doi.org/10.1177/ 1469540516668226

Salette, J. (1997). La typicité: Une notion nouvelle au service du produit, de ceux qui l'élabrent, et de ceux qui le consomment en l'appréciant [Typicality: A new notion at the service of the product, of those who make it thinner, and of those who consume it while appreciating it]. Revue des Oenologues et des Techniques Vitivinicoles et Oenologiques [Review of Oenologists and Vitivinicultural and Oenological Techniques], 85, 11-13.

Slater, D. (2002). Markets, materiality and the 'new economy', in A. Warde and S. Metcalfe (eds.), Market Relations and the Competitive Process (pp. 95-113). Manchester: Manchester University Press.

Spence, M. (1976). Product differentiation and welfare. The American Economic Review, 66(2), 407-414.

Stanziani, A. (2003a). La construction de la qualité du vin, 1880-1914 [Building wine quality, 1880-1914], in A. Stanziani (ed.), La Qualité des Produits en France, XVIIIe-XXe Siècles [The Quality of Products in France, 18th-20th Centuries]. (pp. 123-150). Paris: Berlin.

Stanziani, A. (2003b). La falsification du vin en France, 1880-1905: Un cas de fraude agro-alimentaire [The falsification of wine in France, 1880-1905: A case of agro-food fraud]. Revue d'Histoire Moderne et Contemporaine [Modern and Contemporary History Review], 50-2(2), 154-186. https://doi.org/10.3917/rhmc.502.0154

Stiglitz, J. E. (1987). The causes and consequences of the dependance of quality on prices. Journal of Economic Literature, 25(1), 1-48.

Storchmann, K. (2012). Wine economics. Journal of Wine Economics, 7(1), 1-33. https://doi.org/10.1017/jwe.2012.8

Teil, G. (2012). No such thing as terroir?: Objectivities and the regimes of existence of objects. Science, Technology and Human Values, 37(5), 478-505. https:/ / doi.org/10.1177/0162243911423843

Teil, G. (2021). Amateurs' exploration of wine - A pragmatic study of taste. Theory Culture \& Society, 38(5), 137157. https:/ / doi.org/10.1177/02632764211029347

Teil, G., Barrey, S., Floux, P., and Hennion, A. (2011). Le Vin et l'Environnement: Faire Compter la Différence [Wine and the Environment: Making the Difference Count]. Paris: Presses de l'Ecole des Mines. https://doi.org/10.4000/ books.pressesmines. 514

Teuber, R. (2010). Geographical indications of origin as a tool of product differentiation: The case of coffee. Journal of International Food \& Agribusiness Marketing, 22(3-4), 277-298. https:/ / doi.org/10.1080/08974431003641612

Thiedig, F. and Sylvander, B. (2000). Welcome to the club?: An economical approach to geographical indications in the European Union. German Journal of Agricultural Aconomics, 49(12), 428-437.

Thomas, L. C., Painbéni, S., and Barton, H. (2013). Entrepreneurial marketing within the French wine industry. International Journal of Entrepreneurial Behavior \& Research, 19(2), 238-260. https://doi.org/10.1108/ 13552551311310392

Torre, A. (2002). Les AOC sont-elles des clubs? réflexions sur les conditions de l'action collective localisée, entre coopération et règles formelles [Are AOCs clubs? reflections on the conditions for localized collective action, between cooperation and formal rules]. Revue D'économie Industrielle [Industrial Economy Journal, 100(1), 39-62. https://doi.org/10.3406/rei.2002.984

Universidad de Valladolid. (1975). Edición facsimile reducida no venal de Ordenanzas de S. M. el Rey Felipe II con que se ha de gobernar y guardar la entrada del vino y la venta del en la ciudad de Valladolid impressas por mandado de Valladolid, en casa de Andres de Merchan Impressor de Libros Año 1597 [Non-venal reduced facsimile edition of Ordinances of HM King Felipe II with which the entry of wine and the sale of wine must be governed and kept in the city of Valladolid impressed by order of Valladolid, at the home of Andres de Merchan Printer of Books Year 1597]. Valladolid: Editorial Sever Custa.

Warde, A. (1994). Consumption, identity-formation and uncertainty. Sociology, 28(4), 877-898. https://doi.org/ $10.1177 / 0038038594028004005$

Welsch, W. (1996). Aestheticization processes: Phenomena, distinctions and prospects. Theory, Culture \& Society, 13(1), 1-24. https://doi.org/10.1177/026327696013001001 